\title{
The wildcat Felis silvestris in northern Turkey: assessment of status using camera trapping
}

\author{
ÖZgün EmRe CAN, İRAan Kandemir and İNCí Togan
}

\begin{abstract}
The wildcat Felis silvestris is a protected species in Turkey but the lack of information on its status is an obstacle to conservation initiatives. To assess the status of the species we interviewed local forestry and wildlife personnel and conducted field surveys in selected sites in northern, eastern and western Turkey during 2000-2007. In January-May 2006 we surveyed for the wildcat using 16 passive infrared-trigged camera traps in Yaylacik Research Forest, a $50-\mathrm{km}^{2}$ forest patch in Yenice Forest in northern Turkey. A total sampling effort of 1,200 camera trap days over $40 \mathrm{~km}^{2}$ yielded photo-captures of eight individual wildcats over five sampling occasions. Using the software MARK to estimate population size the closed capturerecapture model $M_{0}$, which assumes a constant capture probability among all occasions and individuals, best fitted the capture history data. The wildcat population size in Yaylacik Research Forest was estimated to be 11 (confidence interval 9-23). Yenice Forest is probably one of the most important areas for the long-term conservation of the wildcat as it is the largest intact forest habitat in Turkey with little human presence, and without human settlements, and with a high diversity of prey species. However, it has been a major logging area and is not protected. The future of Yenice Forest and its wildcat population could be secured by granting this region a protection status and enforcing environmental legislation.
\end{abstract}

Keywords Camera trap, conservation, Felis silvestris, Turkey, wildcat, Yenice Forest

\section{Introduction}

$\mathrm{D}$ espite the high diversity of carnivores in Turkey information about them is limited and there is almost no monitoring of carnivores or other large mammals (Can \& Togan, 2004). Poor knowledge of species ranges and population status hinder conservation initiatives for carnivores (Holloway \& Swift, 1967; Huş, 1974; Turan, 1984).

ÖZgün EMRE CAN* (Corresponding author) Department of Biology, Middle East Technical University, Ankara, Turkey. E-mail emre.can@daad-alumni.de İRFAN KANDEMir Department of Biology, Ankara University, Ankara, Turkey İnci Togan Department of Biology, Middle East Technical University, Turkey

${ }^{*}$ Current address: Hürriyet Caddesi 43/17 Dikmen, 06460 Ankara, Turkey

Received 22 August 2009. Revision requested 8 October 2009.

Accepted 11 December 2009.
Wildcats occur throughout parts of Eurasia and Africa (Nowell \& Jackson, 1996; Sunquist \& Sunquist, 2002; Bashta \& Potish, 2005; Heltai et al., 2006), and are generally associated with forests (Macdonald \& Barrett, 1993; Sunquist \& Sunquist, 2002). They take mostly small prey (rodents and birds) but also catch larger species such as hares (Lepus spp.) and young deer (Cervus spp.; Sunquist \& Sunquist, 2002). Wildcats are solitary and males and females associate only for mating (Sunquist \& Sunquist, 2002), which occurs mostly from mid February to late March, with the young born in April or May (Macdonald \& Barrett, 1993; Sunquist \& Sunquist, 2002). The major threats to wildcats are persecution by humans and hybridization with domestic cats (Macdonald \& Barrett, 1993; Beaumont et al., 2001; Randi et al., 2001; Sunquist \& Sunquist, 2002). Hybridization may threaten (Pierpaoli et al., 2003) and even have caused the extinction of some local wildcat populations (Yamaguchi et al., 2004).

Although categorized globally on the IUCN Red List as Least Concern (Driscoll \& Nowell, 2009) the European wildcat is listed as a Strictly Protected Fauna Species in Annex II of the Convention on the Conservation of European Wildlife and Natural Habitats (Bern Convention), which was ratified by the Turkish Government on 2 May 1984 (Council of Europe, 2008). The species is protected by law in Turkey and any form of hunting or killing is prohibited (Turkish Ministry of Environment and Forestry, 2008).

The objectives of the study reported here were to evaluate the available information on the wildcat and its current status in Turkey, to examine the activity patterns and population size of the wildcat in one particularly important site, the Yaylacik Research Forest, using camera trapping, and to provide baseline data to promote further research on the wildcat in Turkey.

\section{Study area}

The camera-trapping survey was conducted in the c. $50 \mathrm{~km}^{2}$ Yaylackk Research Forest which lies within the c. $750 \mathrm{~km}^{2}$ Yenice Forest in northern Turkey (Fig. 1a), an area with an intact large mammal fauna of global importance (Morrison et al., 2007). Elevations are 100-2,000 m, most of the mean annual precipitation of $1,200 \mathrm{~mm}$ falls in the spring, and the mean number of days per year with snow is 25 (Can \& Togan, 2009). Tree species include spruce Picea orientalis, the Balkan maple Acer hyrcanum, beech Fagus orientalis, Caucasian fir Abies nordmanniana, common ash Fraxinus excelsior, 
European hornbeam Carpinus betulus, Istranca oak Quercus hartwissiana, Norway maple Acer platanoides, Quercus petraea, Scots pine Pinus sylvestris, Turkey oak Quercus cerris and yew Taxus baccata (Lise, 2005; Can \& Togan, 2009). As the entrance to the Yenice Forest is controlled by the forestry service and no recreational activities are allowed, human densities are low throughout the year.

\section{Methods}

\section{Countrywide survey}

We firstly reviewed the available literature on the wildcat in Turkey, which was summarized in part by Kumerloeve (1967) and Turan (1984). We used the most recent forest inventory data and forest map (Turkish Ministry of Environment and Forestry, 2006) to assess potentially suitable habitats for the wildcat. We then conducted a countrywide questionnaire survey, with questionnaires disseminated to 331 local forestry stations, to collect information on the occurrence of the wildcat in the Taurus and South-east Anatolia regions (Fig. 1a). The questionnaire included questions on the occurrence of the wildcat and other mammalian species, habitats, and major threats to habitats and wildlife in general. The distributions of wildcat prey species were identified from Kryštufek \&
Vohralik (2001, 2005). We then, in 2000-2007, made opportunistic visits to selected sites in 21 provinces (Fig. $1 \mathrm{~b}$ ) throughout Turkey to meet local forestry personnel, people and hunters and to collect further information. We visited forest sites to evaluate habitat suitability for wildcats and to document any presence signs (tracks, prey remains and scats) of the species.

\section{Camera-trap survey}

During January-May 2006 we conducted five sessions of camera trapping in the Yaylacık Research Forest, which lies within Yenice Forest (Fig. 1a), using 12 CamTrakker (CamTrakker, Georgia, USA) and four DeerCam (DeerCam, Park Falls, USA) passive infrared camera traps. We divided the $50-\mathrm{km}^{2}$ study area into fifty $1-\mathrm{km}^{2}$ cells using a 1:50,000 map provided by the Central Anatolia Forestry Research Institute of the Turkish Ministry of Forestry. In each session we set up camera traps in an area of $8 \mathrm{~km}^{2}$ for 15 days, and then moved the traps to the next $8-\mathrm{km}^{2}$ area for 15 days, and so on until we had surveyed $40 \mathrm{~km}^{2}$ (Karanth \& Nichols, 2002; Karanth et al., 2004). The average distance between camera traps in each session was c. $1 \mathrm{~km}$. The total survey effort was 1,200 camera trap days.

We placed the camera traps to maximize the total number of photo-captures (Karanth \& Nichols, 2002; Holden et al., 2003; Wallace et al., 2003; Karanth et al.,
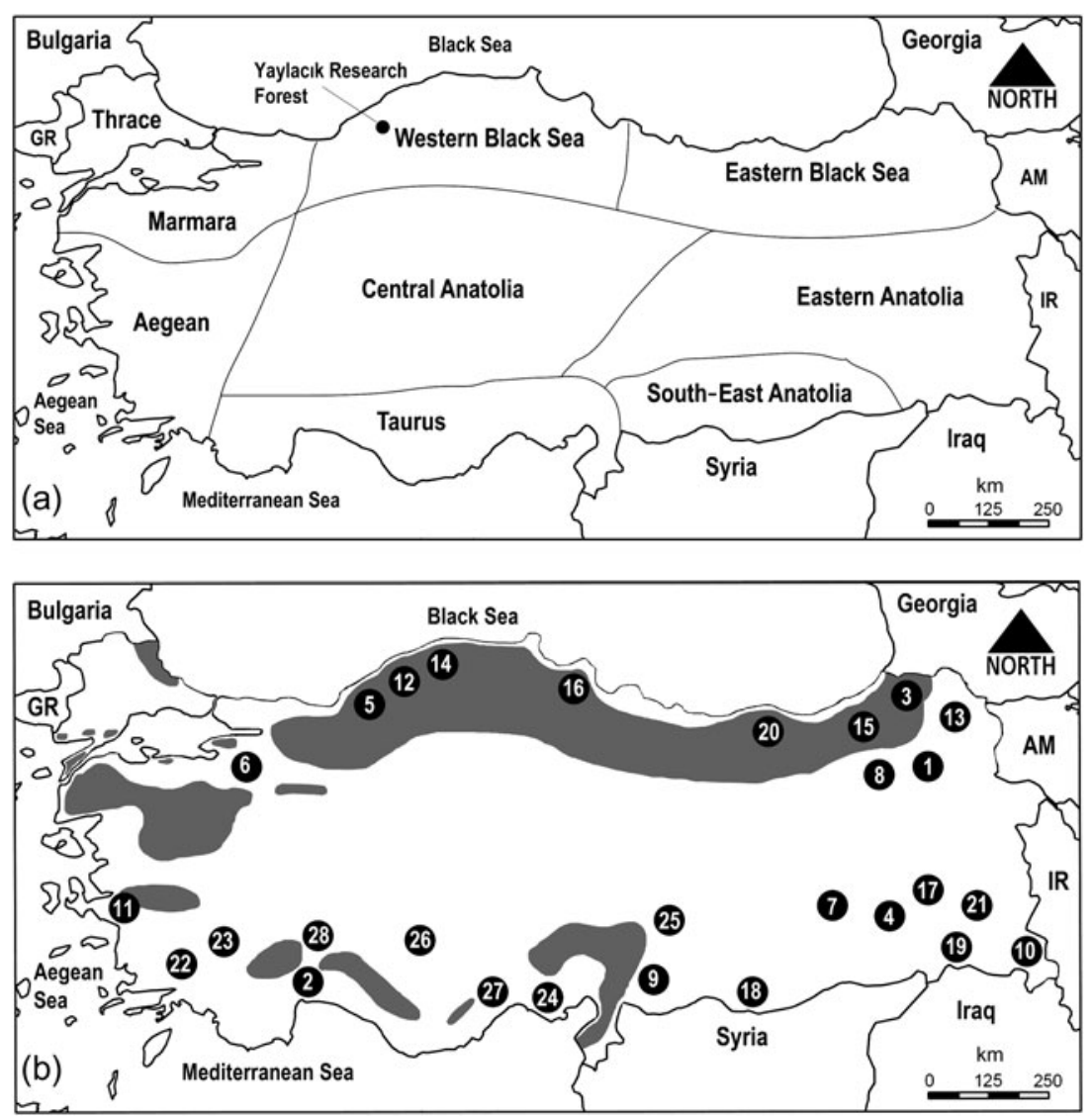

FIG. 1 (a) The regions of Turkey and the camera-trapping survey site, Yaylacık Research Forest in Yenice Forest. (b) Range map of the wildcat in Turkey (shaded areas, based on historical data, interviews and field visits; see text for details) and locations of the provinces in which we visited forest sites to search for signs of the wildcat: 1, Ağr1; 2, Antalya; 3, Artvin; 4, Bitlis; 5, Bolu; 6, Bursa; 7, Diyarbakır; 8, Erzurum; 9, Gaziantep; 10, Hakkari; 11, İzmir; 12, Karabük; 13, Kars; 14,

Kastamonu; 15, Rize; 16, Samsun; 17, Siirt; 18, Şanlıurfa; 19, Şırnak; 20, Trabzon; 21, Van. Other provinces mentioned in the text are: 22, Muğla; 23, Denizli; 24, Adana; 25, Kahramanmaraş; 26, Konya; 27, Mersin; 28, Isparta. 
TABLE 1 Major habitats, distribution, relative abundance and prey species of the wildcat Felis silvestris in Turkey (Fig. 1).

\begin{tabular}{|c|c|c|c|c|}
\hline Region & Major habitats & Distribution & Abundance & Prey species (rodents \& insectivores) \\
\hline Thrace & $\begin{array}{l}\text { Mesic deciduous \& mixed } \\
\text { forests of oak Quercus spp., } \\
\text { beech Fagus orientalis \& } \\
\text { spruce Picea orientalis }\end{array}$ & $\begin{array}{l}\text { Mainly confined to } \\
\text { Kirklareli (Yıldız } \\
\text { Mountains) }\end{array}$ & Uncommon & $\begin{array}{l}\text { European red squirrel Sciurus } \\
\text { vulgaris, dormouse Glis glis, forest } \\
\text { dormouse Dryomis nitedula, water } \\
\text { vole Arvicola terrestris, European } \\
\text { pine vole Microtus subterraneus, } \\
\text { Eastern hedgehog Erinaceus } \\
\text { concolor, pygmy shrew Sorex } \\
\text { minutes, common shrew Sorex } \\
\text { araneus, Miller's water shrew } \\
\text { Neomys anomalus, common mole } \\
\text { Talpa europea }\end{array}$ \\
\hline $\begin{array}{c}\text { Marmara \& } \\
\text { Aegean }\end{array}$ & $\begin{array}{l}\text { Mesic deciduous \& mixed } \\
\text { forests of Quercus spp., } \\
\text { F. orientalis \& P. orientalis, } \\
\text { Mediterranean maquis \& } \\
\text { woodland oak Quercus } \\
\text { calliprinos, Quercus cerris } \\
\text { \& pine Pinus brutia \& } \\
\text { Pinus nigra }\end{array}$ & $\begin{array}{l}\text { Mainly confined to } \\
\text { Adapazarı, Balıkesir, } \\
\text { Bilecik, Bursa, } \\
\text { Çanakkale \& Burdur \& } \\
\text { doubtful in Denizli, } \\
\text { Manisa, Muğla \& } \\
\text { Uşak }\end{array}$ & Uncommon & $\begin{array}{l}\text { Caucasian squirrel Sciurus } \\
\text { anomalus, D. nitedula, E. concolor }\end{array}$ \\
\hline Taurus & $\begin{array}{l}\text { Mediterranean maquis \& } \\
\text { woodland oak } Q \text {. } \\
\text { calliprinos, Q. cerris \& } \\
\text { pine P. brutia, P. nigra }\end{array}$ & $\begin{array}{l}\text { Distribution is mainly } \\
\text { confined to Antalya, } \\
\text { Isparta, Adana, } \\
\text { Osmaniye \& } \\
\text { Kahramanmaraş }\end{array}$ & Rare & S. anomalus, D. nitedula, E. concolor \\
\hline $\begin{array}{l}\text { Western Black } \\
\text { Sea Mountains }\end{array}$ & $\begin{array}{l}\text { Mesic deciduous \& mixed } \\
\text { forests of Quercus spp., } \\
\text { F. orientalis \& P. orientalis }\end{array}$ & $\begin{array}{l}\text { Distribution is mainly } \\
\text { confined to Amasya, } \\
\text { Bartın, Bolu Düzce, } \\
\text { Eskişehir, Karabük, } \\
\text { Kastamonu, Samsun, } \\
\text { Sinop, Ordu \& } \\
\text { Zonguldak }\end{array}$ & Common & $\begin{array}{l}\text { S. anomalus, G. glis, hazel dormouse } \\
\text { Muscardinus avellanarius, D. } \\
\text { nitedula, bank vole Clethrionomys } \\
\text { glareolus, A. terrestris, } M \text {. } \\
\text { subterraneus, E. concolor, Caucasian } \\
\text { pygmy shrew Sorex volnuchini, } N \text {. } \\
\text { anomalus, Transcaucasian water } \\
\text { shrew Neomys teres, Levant mole } \\
\text { Talpa levantis, blind mole Talpa } \\
\text { caeca }\end{array}$ \\
\hline $\begin{array}{l}\text { Eastern Black } \\
\text { Sea Mountains }\end{array}$ & $\begin{array}{l}\text { Mesic deciduous \& mixed } \\
\text { forests of Quercus spp., } \\
\text { F. orientalis \& P. orientalis }\end{array}$ & $\begin{array}{l}\text { Distribution is mainly } \\
\text { confined to Artvin, } \\
\text { Trabzon \& Giresun }\end{array}$ & Common & $\begin{array}{l}\text { S. anomalus, G. glis, M. avellanarius, } \\
\text { D. nitedula, C. glareolus, A. terrestris, } \\
\text { Major's pine vole Microtus majori, } \\
\text { Robert's snow vole Chionomys } \\
\text { roberti, E. concolor, S. volnuchini, } \\
\text { Radde's shrew Sorex raddei, N. teres, } \\
\text { T. levantis }\end{array}$ \\
\hline Eastern Anatolia & $\begin{array}{l}\text { Anatolian Artemisia steppe, } \\
\text { mosaic of Artemisia steppe } \\
\text { \& oak woodland }\end{array}$ & $\begin{array}{l}\text { Bitlis, Bingöl, Hakkari, } \\
\text { Muş \& Siirt }\end{array}$ & $\begin{array}{l}\text { Very rare or } \\
\text { extinct }\end{array}$ & D. nitedula, E. concolor, A. terrestris \\
\hline $\begin{array}{l}\text { Central \& South- } \\
\text { East Anatolia }\end{array}$ & Anatolian Artemisia steppe & Not found & & \\
\hline
\end{tabular}

2004; Maffei et al., 2004; Silver, 2004; Wegge et al., 2004) and recorded their locations with a global positioning system. The camera traps were set for a 3-minute delay between photographs and 24-hour operation. Each camera trap was attached to a tree with padlocks, to prevent theft. Camera-trap performance was checked with test shots at the beginning of each session. After each session all films and batteries were replaced.
Individual camera-trapped wildcats were identified by general physical appearance and the unique patterns of tail rings. Assuming that timing of wildcat captures reflects their activity pattern, we grouped photographs into 6-hour intervals (Kawanishi, 2002; Maffei et al., 2005; Azlan \& Sharma, 2006; Bitetti et al., 2006; Dillon \& Kelly, 2007).

We constructed a capture history matrix of is (captures) and os (non-captures) of individual wildcats across the five 
sampling occasions. The software MARK was used to estimate the wildcat population size using the assumption of population closure (White \& Burnham, 1999). MARK offers four main population size estimators: model $M_{\mathrm{o}}$ (capture probabilities of individuals are constant regardless of time, behaviour or heterogeneity in captures), model $M_{\mathrm{h}}$ (capture probabilities of individuals are intrinsically heterogeneous), model $M_{\mathrm{b}}$ (capture probabilities depend on animal behaviour, and model $M_{\mathrm{t}}$ (capture probabilities are time specific). There are also four complex models $\left(M_{\mathrm{bh}}\right.$, $M_{\mathrm{th}}, M_{\mathrm{tb}}$ and $\left.M_{\mathrm{tbh}}\right)$ that incorporate the effects of heterogeneity, trap response and time in various combinations. To select the best-fit model and assess its parameters we used the model selection function of MARK, which scores the models between o (the poorest model) and 1 (the best model). We used a $\chi^{2}$ goodness-of-fit test (Daniel, 1999) to determine the relationship between wildcat captures and location of camera traps on forest roads, trails and slopes.

\section{Results}

\section{Countrywide survey}

According to the questionnaire results and the information available in the literature the wildcat is present in the Thrace, Marmara, Aegean, Taurus, Western and Eastern Black Sea Mountains and Eastern Anatolia regions of Turkey (Fig. 1b). The Western and Eastern Black Sea Mountains are the most suitable regions for wildcats given the extent of suitable habitat and the diversity of prey (Table 1). Thrace has a diversity of suitable prey species.

The prime wildcat habitats in Turkey are characterized by mesic deciduous and mixed forests of oaks Quercus spp., beech $F$. orientalis and spruce $P$. orientalis in northern Turkey. We did not document presence of the wildcat at the sites we visited in Ağrl, Bitlis, Hakkari, Kars, Şanlıurfa, Siirt, Şırnak and Van. The questionnaire study conducted in the Taurus region provided information on the occurrence of the species in southern Turkey. All the respondents of the questionnaire survey from Muğla $(\mathrm{n}=45)$ and Denizli $(\mathrm{n}=34)$ stated that the wildcat is not present there. According to the questionnaire responses $(n=252)$ from Adana, Antalya, Kahramanmaraş, Konya, Mersin and Isparta the wildcat is present in these provinces. The distribution map (Fig. 1b) was produced by synthesizing the results of the field visits, questionnaire responses and the forest map of Turkey.

\section{Camera-trap survey}

The camera-trap survey documented the wildcat in the Yaylacık Research Forest (Plate 1). We obtained 402 records of animals of which 22 were of wildcats and 13 were appropriate for individual recognition. Relative abundance

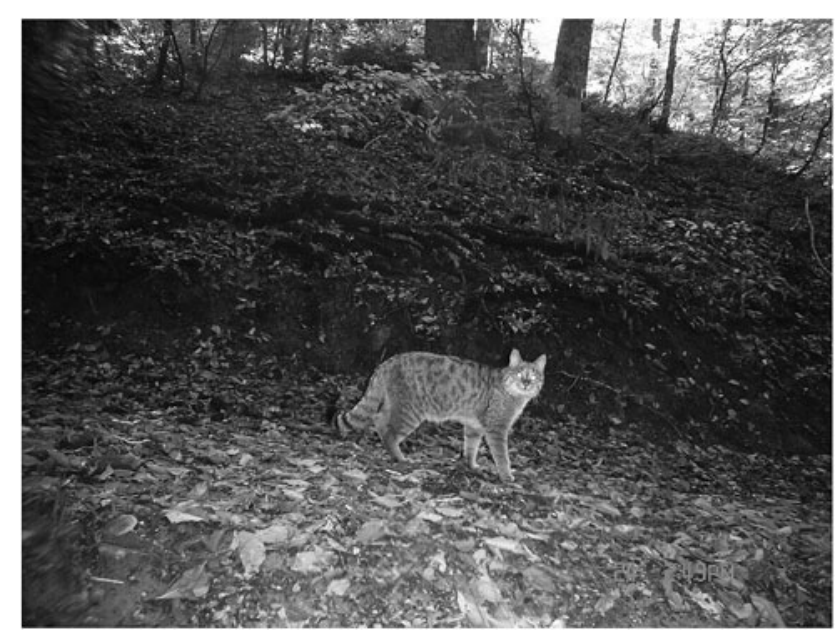

Plate 1 Camera-trap photograph of a wildcat in Yaylacik Research Forest (Fig. 1a).

of wildcats was 18.3 per 1,00o camera-trap days. Eight different individual wildcats were identified from 12 cameratrap records (Table 2) across the five camera-trap sessions, i.e. an average of 150 camera-trap days were required to document the presence of an individual. The assumption of population closure, checked with MARK, was not violated $\left(\chi^{2}=4.41354, \mathrm{df}=2, \mathrm{P}=0.11006\right)$. The model selection algorithm selected the null model $M_{\mathrm{o}}$ as the best fit. The estimated population size was $11.00 \pm$ SE 2.97 (95\% confidence interval 9-23). The distribution of the 80 camera-trap stations on forest roads, trails and slopes is given in Table 3 . Captures of wildcats did not differ significantly across these location types $\left(\chi^{2}=0.491, P>0.05\right)$. Activity patterns of wildcats in the Yaylackk Research Forest were equally diurnal (06.00-18.00, 50.4\%) and nocturnal (18.00-06.00, 49.6\%; Fig. 2).

\section{Discussion}

Kumerloeve (1967) provided the first information on the occurrence of the wildcat throughout Turkey. Turan (1984) later modified the map of Kumerloeve (1967), showing

TABLE 2 The capture history of eight individual wildcats cameratrapped in the Yaylacik Research Forest across five sampling occasions (see text for details).

\begin{tabular}{ll}
\hline Individual & Capture history \\
\hline wc1 & 01000 \\
wc2 & 00101 \\
wc3 & 00110 \\
wc4 & 00001 \\
wc5 & 00001 \\
wc6 & 00011 \\
wc7 & 00101 \\
wc8 & 00100 \\
\hline
\end{tabular}


TABLE 3 Number of camera-trap stations, camera-trap nights and wildcat captures on forest roads, trails and slopes.

\begin{tabular}{lcccr}
\hline & $\begin{array}{c}\text { Forest } \\
\text { roads }\end{array}$ & Trails & Slopes & Total \\
\hline $\begin{array}{c}\text { No. of camera- } \\
\text { trap stations }\end{array}$ & 31 & 30 & 19 & 80 \\
$\begin{array}{c}\text { No. of camera- } \\
\text { trap nights }\end{array}$ & 465 & 460 & 285 & 1,200 \\
$\begin{array}{c}\text { No. of captures } \\
\text { (capture rate } \\
\text { per 100 camera- } \\
\text { trap nights) }\end{array}$ & $5(1.08)$ & $11(2.39)$ & $5(1.75)$ & $21(1.75)$ \\
\hline
\end{tabular}

a greater range for the wildcat. Reviewing the available information we conclude that the current range of the species is much narrower than previously believed. We failed to document the presence of wildcats in the provinces of Ağrı, Diyarbakır, Gaziantep, İzmir, Kars, Şanlıurfa, Ş1rnak and Van, from where the species has probably vanished since Kumerloeve (1967) drew his map. Turan (1984) suggested that the wildcat occurred in the Marmara, Aegean and Taurus regions but we conclude that its current day distribution is limited there. In the Taurus region most forests are conifer and maquis, inappropriate for wildcats, and thus the species range is mainly confined to the Kahramanmarass region, which contains the largest area of deciduous forest. We believe that the presence of wildcats in Erzurum, Bitlis, Siirt and Hakkari is doubtful because we did not document the species in the sites we visited. However, wildcat signs are difficult to find and may be confused with other species such as foxes Vulpes vulpes, jungle cats Felis chaus and martens Martes sp. If present in eastern Turkey the wildcat population there is isolated from that in other parts of the country and would be a priority region for conservation of the species.

Most of the prime wildcat habitat is in northern Turkey, including Thrace, and there is a need for conservation initiatives in this region. In the Marmara, Aegean and Taurus regions the wildcat population is heavily fragmented, possibly consisting of several isolated subpopulations, and the issue of connectivity deserves further research.
Although wildcats are normally crepuscular and nocturnal (Macdonald \& Barrett, 1993) in the Yaylacık Research Forest they are also diurnal (although our sample size of 22 photo-captures is small). Human-related land-use types such as roads can affect the behaviour of wildcats (Klar et al., 2008) but photo-capture rates in Yaylacik Research Forest did not differ between forest roads, trails and slopes.

The Yenice Forest $\left(750 \mathrm{~km}^{2}\right)$, which includes the Yaylacik Research Forest $\left(50 \mathrm{~km}^{2}\right)$ and two small protected areas $\left(\right.$ c. $12 \mathrm{~km}^{2}$ ), is one of the largest intact forests in Turkey but it does not have a protection status. Considering the size of the area, the general absence of human disturbance and the availability of prey species, Yenice Forest probably holds one of the largest wildcat populations in the country and may be one of the most important areas for conservation of the species. However, some sites within Yenice Forest have been logged, generating income for the state and local communities (Lise, 2005). The Yaylacik Research Forest is meant to be used only for research purposes but selective logging is currently allowed during some part of the year to mitigate the pressure from local communities for the use of forest resources (Can \& Togan, 2009). Nevertheless, the remoteness and intactness of the region reduces the risk of hybridization with the domestic cat Felis cattus, which is a main concern in most parts of Europe (Beaumont et al., 2001; Pierpaoli et al., 2003; Yamaguchi et al., 2004). The future of Yenice Forest will only be secured if it is given a protection status and the appropriate environmental legislation is enforced.

Political pressure from local communities to utilize parts of Yenice Forest is increasing (Can \& Togan, 2009) and the Ministry of Environment and Forestry General Directorate of Forestry is considering selective cutting in some parts of Yaylacik Research Forest. We have presented our findings to the relevant authorities and urge the Turkish Ministry of Environment and Forestry authorities to reconsider any future logging in Yaylacik Research Forest. We recommend that the Turkish nature conservation organizations, particularly WWF Turkey, which identified Yenice Forest as a global forest hotspot, focus their attention on this region.

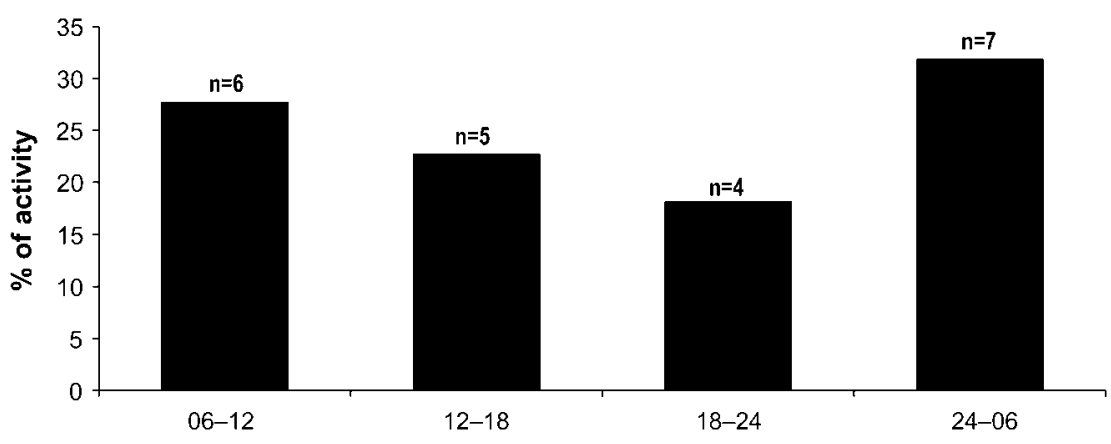

FIG. 2 The activity pattern of wildcats camera-trapped in Yaylackk Research Forest, summarized in 6-hour periods. 


\section{Acknowledgements}

We thank Tuğba Can, Yıldıray Lise, Emin Nasuhoğlu, Dave Garshelis and Fridolin Zimmermann for their assistance, Metin Karadağ, Murat Başar, Durmuş Kanca, Mehmet Özgün and İsmet Telli for help with fieldwork, and two anonymous reviewers who helped us improve this article.

\section{References}

Azlan, J.M. \& Sharma, D.S.K. (2006) The diversity and activity patterns of wild felids in a secondary forest in Peninsular Malaysia. Oryx, 40, 36-41.

Bashta, A. \& Pотіsh, L. (2005) Population status and distribution of the wildcat Felis silvestris (Felidae, Carnivora), in Transcarpathia (Ukraine). Nature Conservation, 61, 53-59.

Beaumont, M., Barratt, E.M., Gottelli, D., Kitchener, A.C., Daniels, M.J., Pritchard, J.K. \& Bruford, M.W. (2001) Genetic diversity and introgression in the Scottish wildcat. Molecular Ecology, 10, 319-336.

Bitetti, M.S.D., Paviolo, A. \& De Angelo, C. (2006) Density, habitat use and activity patterns of ocelots (Leopardus pardalis) in the Atlantic Forest of Misiones, Argentina. Journal of Zoology, $270,153-163$.

CAN, Ö.E. \& Togan, İ. (2004) Status and management of brown bears in Turkey. Ursus, 15, 48-53.

CAN, Ö.E. \& TogAN, İ. (2009) Camera trapping of large mammals in Yenice Forest, Turkey: local information versus camera traps. Oryx, 43, 427-430.

Council of Europe (2008) List of Declarations Made with Respect to Treaty No. 104 (Convention on the Conservation of European Wildlife and Natural Habitats). Http://conventions.coe.int [accessed 21 March 2008].

D Aniel, W. (1999) Biostatistics. A Foundation for Analysis in the Health Sciences. John Wiley, New York, USA.

Dillon, A. \& Kelly, M.J. (2007) Ocelot Leopardus pardalis in Belize: the impact of trap spacing and distance moved on density estimate. Oryx, 41, 469-477.

Driscoll, C. \& Nowell, K. (2009) Felis silvestris. In IUCN Red List of Threatened Species v. 2010.2. Http://www.iucnredlist.org [accessed 6 September 2009].

Heltai, M., Biró, Z. \& Szemethy, L. (2006) The changes of distribution and population density of wildcats Felis silvestris Schreber, 1775 in Hungary between 1987-2001. Nature Conservation, 62, 37-42.

Holden, J., Yanuar, A. \& Martyr, D.J. (2003) The Asian Tapir in Kerinci Seblat National Park, Sumatra: evidence collected through photo-trapping. Oryx, 37, 34-40.

Holloway, C.W. \& Swift, L.W. (1967) The Management of Large Mammals in Turkey. Report TA 2391. Food and Agriculture Organization, Rome, Italy.

Huş, S. (1974) Av hayvanları ve avcılık. Istanbul Orman Fakültesi Yayınları, Kurtulmuş Matbaası, Istanbul, Turkey.

Karanth, K.U., Chundawat, R.S., Nichols, J.D. \& Kumar, N.S. (2004) Estimation of tiger densities in the tropical dry forests of Panna, Central India, using photographic capture-recapture sampling. Animal Conservation, 7, 285-290.

Karanth, K.U. \& Nichols, J.D. (eds) (2002) Monitoring Tigers and their Prey. Centre for Wildlife Studies, Bangalore, India.

KAW ANishi, K. (2002) Population status of tigers (Panthera tigris) in a primary rainforest of Peninsular Malaysia. $\mathrm{PhD}$ thesis. University of Florida, Florida, USA.
Klar, N., Fernandez, N., Kramer-Schadt, S., Herrmann, M., Trinzen, M., Büttner, I. \& Niemitz, C. (2008) Habitat selection models for European wildcat conservation. Biological Conservation, 141, 308-319.

Kryštufek, B. \& Vohralik, V. (2001) Mammals of Turkey and Cyprus: Introduction Checklist Insectivora. University of Primorska, Science and Research Center, Koper, Slovenia.

Kryštufek, B. \& Vohralik, V. (2005) Mammals of Turkey and Cyprus: Rodentia. University of Primorska, Science and Research Center, Koper, Slovenia.

Kumerloeve, H. (1967) Zur Verbreitung kleinasiatischer Raub- und Huftiere sowie einiger Großnager. Säugetierkundliche Mitteilungen, 15, 337-409.

Lise, Y. (2005) Yenice Ormanlar1. National Geographic Turkey, Istanbul, Turkey.

Macdonald, D.W. \& Barrett, P. (1993) Field Guide: Mammals of Britain and Europe. Harper Collins, London, UK.

Maffei, L., Cuellar, E. \& Noss, A. (2004) One thousand jaguars (Panthera onca) in Bolivia's Chaco? Camera trapping in the KaaIya National Park. Journal of Zoology, 262, 295-304.

Maffei, L., Noss, A.J., Cuellar, E. \& Rumiz, D.I. (2005) Ocelot (Felis pardalis) population densities, activity, and ranging behaviour in the dry forests of eastern Bolivia: data from camera trapping. Journal of Tropical Ecology, 21, 349-353.

Morrison, J.C., Sechrest, W., Dinerstein, E., Wilcove, D.S. \& Lamoreux, J.F. (2007) Persistence of large mammal faunas as indicators of global human impacts. Journal of Mammalogy, 88, 1363-1380.

Nowell, K., \& Jackson, P. (eds) (1996) Wildcats: Status Survey and Conservation Action Plan. IUCN, Gland, Switzerland.

Pierpaoli, M., Birò, Z.S., Herrmann, M., Hupe, K., Fernandes, M., RAGNi, B. et al. (2003) Genetic distinction of wildcat (Felis silvestris) populations in Europe, and hybridisation with domestic cats in Hungary. Molecular Ecology, 12, 2585-2598.

Randi, E., Pierpaoli, M., Beaumont, M., Ragni, B. \& Sforzi, A. (2001) Genetic identification of wild and domestic cats (Felis silvestris) and their hybrids using bayesian clustering methods. Molecular Biology and Evolution, 18, 1679-1693.

Silver, S. (2004) Assessing Jaguar Abundance Using Remotely Triggered Cameras. Jaguar Conservation Program, Wildlife Conservation Society, New York, USA.

Sunquist, M. \& Sunquist, F. (2002) Wildcats of the World. The University of Chicago Press, Chicago, USA.

Turan, N. (1984) Türkiye'nin av ve yaban hayvanlar1: Memeliler. Ongun Kardeşler Matbaacılık Sanayii, Ankara, Turkey.

Turkish Ministry of Environment and Forestry (2006) Orman Varlı̆gımız. Turkish Ministry of Environment and Forestry, Ankara, Turkey.

Turkish Ministry of Environment and Forestry (2008) Merkez Av Komisyonu Kararlar1 2008-2009. Turkish Ministry of Environment and Forestry Publication, Ankara, Turkey.

Wallace, R.B., Gomez, H., Ayala, G. \& Espinoza, F. (2003) Camera trapping for jaguar (Panthera onca) in the Tuichi Valley, Bolivia. Mastozoología Neotropical. Journal of Neotropical Mammals, 10, 133-139.

Wegge, P., Pokheral, C.P. \& Jnawali, S.R. (2004) Effects of trapping effort and trap shyness on estimates of tiger abundance from camera trap studies. Animal Conservation, 7, 251-256.

White, G.C. \& Burnham, K.P. (1999) Program MARK: survival estimation from populations of marked animals. Bird Study, 46(Suppl.), 120-138.

YamaguChi, N., Kitchener, A.C., Ward, J.M., Driscoll, C.A. \& MaCdonald, D.W. (2004) Craniological differentiation amongst 
wild-living cats in Britain and southern Africa: natural variation or the effects of hybridisation? Animal Conservation, 7, 339-351.

\section{Biographical sketches}

ÖZGÜN EMRE CAN's research interests are in large carnivore monitoring and conservation. He is the founder of the Carnivore Initiative for Turkey, co-chair of the IUCN Bear Specialist Group South Asia Brown Bear Expert Team and a member of the IUCN
Wolf, Hyaena, Canid and Cat Specialist Groups. İRA AN KANDEmiR studies population biology and genetics, including the molecular systematics of honeybees in Turkey and the Middle East, and is now applying genetic techniques to rodents such as Rattus, Nannospalax, Clethryonomys and Apodemus. İNCí Togan carries out research on population biology and genetics. She has previously studied the brown trout of Turkey and is currently studying the evolutionary history of human populations, domestic sheep and dogs in Anatolia. Using these studies she is hoping to be able to identify a strategy to prioritize the conservation of Anatolian sheep breeds. 